\title{
Seasonal dynamics of bacterioplankton community structure at a coastal station in the western English Channel
}

\author{
I. Mary ${ }^{1, *}$, D. G. Cummings ${ }^{2}$, I. C. Biegala ${ }^{3}$, P. H. Burkill ${ }^{1}$, S. D. Archer $^{2}$, \\ M. V. Zubkov ${ }^{1}$ \\ ${ }^{1}$ National Oceanography Centre, Southampton, Waterfront Campus, European Way, Southampton SO14 3ZH, UK \\ ${ }^{2}$ PlymouthMarine Laboratory, Prospect Place, West Hoe, Plymouth PL1 DH, UK \\ ${ }^{3}$ Institut de Recherche pour le Développement, Centre d'Océanologie de Marseille, Rue de la Batterie des Lions, \\ 13007 Marseille, France
}

\begin{abstract}
An annual study of the bacterioplankton community structure was carried out at Stn L4 $\left(50^{\circ} 15^{\prime} \mathrm{N}, 04^{\circ} 13^{\prime} \mathrm{W}\right)$ in the western English Channel between August 2003 and July 2004. Bacterioplankton abundance and community structure were assessed using flow cytometry and fluorescence in situ hybridization (FISH) with rRNA-targeted oligonucleotide probes, respectively. The Eubacteria domain dominated over the Archaea domain (<15\%) at the highest phylogenetic level. The Sphingobacteria-Flavobacteria group of the Bacteroidetes phylum (SFB) numerically dominated in spring and early summer. The $\alpha$-Proteobacteria dominated from late summer to winter. The SAR11 clade represented $\sim 13 \%$ of the microbial community throughout the year and accounted for up to $69 \%$ of $\alpha$-Proteobacteria in late spring. Annually, $\gamma$-Proteobacteria were 2 or 3 times less abundant than the other groups and showed no obvious seasonal trend. The SAR86 cluster accounted for up to half of $\gamma$-Proteobacteria when it peaked in summer. Consequently, we found that community structure at higher taxonomic level did not change dramatically with season but lower level phylogenetic groups showed pronounced seasonal peaks.
\end{abstract}

KEY WORDS: Bacterioplankton - Seasonal variability · Community structure · English Channel • Fluorescence in situ hybridization

\section{INTRODUCTION}

Bacterioplankton play key roles in many biogeochemical processes (Ducklow \& Carlson 1992, Azam 1998, Ducklow 2000). Understanding which bacterioplankton communities dominate and what they respond to remains a fundamental ecological question. An important first step towards understanding the roles of various prokaryotes in the ocean is determining the numbers and relative abundances of different bacterioplankton groups (Giovannoni \& Rappé 2000).

Fluorescence in situ hybridization (FISH) with rRNAtargeted oligonucleotide probes selectively labels microbial cells with defined phylogenetic affiliations (Amann et al. 1995, 1997). FISH has proved a useful tool for monitoring spatial (Alfreider et al. 1996) and temporal (Pernthaler et al. 1997) dynamics of different phylogenetic groups of the planktonic microbial community in marine and freshwater environments (Glockner et al. 1999, Pernthaler et al. 2002b, 2004).

Few seasonal studies on the dynamics of defined phylogenetic groups of bacteria in natural habitats have been carried out so far (Pernthaler et al. 1998, Glockner et al. 1999, Zwisler et al. 2003). Previous investigations have reported that $\beta$-Proteobacteria dominate in freshwater systems (Hiorns et al. 1997), while marine microbial communities are usually dominated by bacteria that are phylogenetically affiliated with $\alpha$-Proteobacteria and with members of the SFB group (Glockner et al. 1999). Bacterioplankton com- 
munity biomass, function, structure, and diversity are known to change between winter and summer (Pernthaler et al. 1998, Zaccone et al. 2002). Schauer et al. (2003) showed the overall stability in time of the taxonomic composition of the bacterioplankton in coastal marine system, with gradual changes throughout the year revealing a substitution of closely related phylotypes during the seasonal cycle. Crump et al. (2003) demonstrated that shifts in bacterioplankton community composition were related to seasonal cycles in the source and lability of dissolved organic matter. Similarly, succession in marine bacterioplankton assemblages occurred in response to seasonal shifts in water column stability and water temperature, suggesting that bacterioplankton community composition may demonstrate an annual pattern of variability (Murray et al. 1998). Other studies have demonstrated relationships between bacterioplankton community composition and seasonal dynamics of other members of the aquatic food web (Hofle et al. 1999, Fandino et al. 2001, Hahn \& Hofle 2001, Arrieta \& Herndl 2002).

A typical seasonal dynamic in temporal coastal waters still remains to be established. Previous mesocosm experiments showed dramatic changes in the composition of the bacterial assemblage on daily to weekly time scales (van Hannen et al. 1999, Schäfer et al. 2001). However, it is not clear whether these changes are frequent in the field, although in some situations, such as during phytoplankton blooms, strong changes in numbers and phylogenetic shifts of the bacterial assemblage have been observed (Fandino et al. 2001, Yager et al. 2001). Only a few studies have addressed temporal changes during a whole seasonal cycle in natural environments in freshwater (Lindström 1998, Pernthaler et al. 1998) or coastal (Murray et al. 1998, Pinhassi \& Hagström 2000, Schauer et al. 2003) environments.

The aim of the present study was to examine seasonal variation in phylogenetic composition of the bacterioplankton community at a station off Plymouth in the western English Channel (Stn L4). The site is characterised by a large seasonal variation in physical forcing and exhibits a diverse succession of phytoplankton blooms through the spring, summer and autumn, making it an ideal place to study seasonality of bacterioplankton composition.

\section{MATERIALS AND METHODS}

Sampling site. Water samples were collected once a week at $2 \mathrm{~m}$ depth at Stn L4 $\left(50^{\circ} 15^{\prime} \mathrm{N}, 04^{\circ} 13^{\prime} \mathrm{W}\right.$, water depth $\sim 55 \mathrm{~m}$ ) off Plymouth in the English Channel from August 2003 to August 2004. Bacterial abundance in surface waters was also monitored from July 1998 to December 2001.
Flow cytometry. Bacterial abundance in surface waters was monitored from July 1998 to December 2001 and from August 2003 to July 2004 with a FACSort flow cytometer (Becton Dickinson) after DNA staining as described in Marie et al. (1997). Yellow-green beads of $0.5 \mu \mathrm{m}$ diameter (Fluoesbrite Microparticles; Polysciences) were used as a flow cytometric internal standard in order to normalise samples (Zubkov et al. 2002).

Tyramide signal amplification-fluorescent in situ hybridization (TSA-FISH). For TSA-FISH, $50 \mathrm{ml} \mathrm{sam-}$ ples were fixed with $1 \%$ paraformaldehyde (PFA) and harvested on $0.2 \mu \mathrm{m}$ (pore-size) polycarbonate filters. TSA-FISH was performed as described in Biegala et al. (2002) with some modifications as described below. Before hybridization, prokaryotic cells were partially lysed by placing the filters for $1 \mathrm{~h}$ at $37^{\circ} \mathrm{C}$ in $1 \mathrm{ml}$ of $100 \mathrm{~g} \mathrm{ml}^{-1}$ lysozyme (47 $000 \mathrm{U} \mathrm{mg}^{-1}$, Sigma-Aldrich) in $0.1 \mathrm{M}$ Tris- $\mathrm{HCl}$ and $0.05 \mathrm{M}$ EDTA (pH 7.7). The enzymatic reaction was stopped by rinsing the filter 3 times in $5 \mathrm{ml}$ of sterile water for $1 \mathrm{~min}$. Filters were then placed for $30 \mathrm{~min}$ at $37^{\circ} \mathrm{C}$ in $1 \mathrm{ml}$ of $60 \mathrm{U}$ Achromopeptidase (2600 $\mathrm{U} \mathrm{mg}^{-1}$, Sigma-Aldrich) in $0.1 \mathrm{M}$ Tris-HCl and 0.05 MEDTA ( $\mathrm{pH} 7.7$ ) and the enzyme reaction was stopped by rinsing the filter 3 times in $5 \mathrm{ml}$ of sterile water for $1 \mathrm{~min}$. Filters were then dehydrated in a second ethanol series $(50,80,100 \%, 3$ min each) and dried.

Oligonucleotide probes. The probe sequences, hybridization conditions, and references are given in Table 1. The probe GAM42a was used with competitor oligonucleotides as described previously (Manz et al. 1992). The probes EUBI (EUB338), EUBII and EUBIII were pooled to maximise targeting the Eubacteria (Amann et al. 1990, Daims et al. 1999). A mixture of 2 probes, CREN554 and EURY806 (Massana et al. 1997, J. Pernthaler unpubl. data, ), which detect Crenarchaea and Euryarchea respectively, was used to detect Archaea. A mixture of 2 published probes was used to enhance the detection of the SAR11 clade (Morris et al. 2002).

Microscopy counts. The filter sections were inspected and cells were counted under a Zeiss Axioplan II motorised epifluorescence microscope (Carl Zeiss), equipped with a 100× UV Plan Apochromat objective and excitation/emission filters 360/420 for DAPI and 490/515 for FITC and an automated image analysis system KS300 (Image Associates). For each sample and probe, about 1000 cells were counted per sample using automatic exposure. All probe-specific cell counts are presented as the percentage of cells visualized by DAPI.

Statistical analysis. Means and standard deviations for 8 to 10 fields of view, representing about 1000 cells, across the filters were calculated. Reproducibility of the hybridization procedure was also checked using independent filters. A $t$-test was used to statistically compare the means of the data between each month 
Table 1. Probes used in the present study. FA: percentage of formamide in in situ hybridization buffer

\begin{tabular}{|lllcl|}
\hline Probe & Specificity & Sequence $\left(5^{\prime}-3^{\prime}\right)$ of probe & FA (\%) & Source \\
\hline EUB338/I & Eubacteria & GCTGCCTCCCGTAGGAGT & 50 & Amann et al. (1990) \\
EUBII & Eubacteria & GCAGCCACCCGTAGGTGT & 50 & Daims et al. (1999) \\
EUBIII & Eubacteria & GCTGCCACCCGTAGGTGT & 50 & Daims et al. (1999) \\
CF319a & SFB & TGGTCCGTGTCTCAGTAC & 50 & Manz et al. (1996) \\
Alf968 & - -Proteobacteria & GGTAAGGTCTGCGCGTT & 50 & Glockner et al. (1999) \\
Gam42a & $\gamma$-Proteobacteria & GCCTTCCCACATCGTTT & 50 & Manz et al. (1992) \\
RSB67 & Roseobacter & CGCTCCACCCGAAGGTAG & 40 & Zubkov et al. (2001a) \\
Sar86/1245 & SAR86 cluster & TTAGCGTCCGTCTGTAT & 50 & Zubkov et al. (2001b) \\
SAR11-152R & SAR11 & ATTAGCACAAGTTTCCYCGTT & 50 & Morris et al. (2002) \\
SAR11-542R & SAR11 & TCCGAACTACGCTAGGTC & 50 & Morris et al. (2002) \\
Eury806 & Some marine Euryarchaea & CACAGCGTTTACACCTAG & 20 & J. Pernthaler (unpubl.) \\
Cren554 & 50\% of Crenarchaea & TTAGGCCCAATAATCMTCCT & 20 & Massana et al. (1997) \\
\hline
\end{tabular}

and the following one. An F-test was carried out to examine the variance between the bacterial groups and total bacterioplankton abundance.

\section{RESULTS}

\section{Bacterioplankton abundance}

Total bacterioplankton numbers ranged from $0.2 \times 10^{6}$ to $1.6 \times 10^{6}$ cells $\mathrm{ml}^{-1}$ during the studied annual cycle (Fig. 1). Similar trends in bacterioplankton abundance occurred between 1998-2001 and 2003-2004: a general increase from February to September and a decrease from October to January. Therefore the studied annual cycle is typical for these temporal coastal waters.

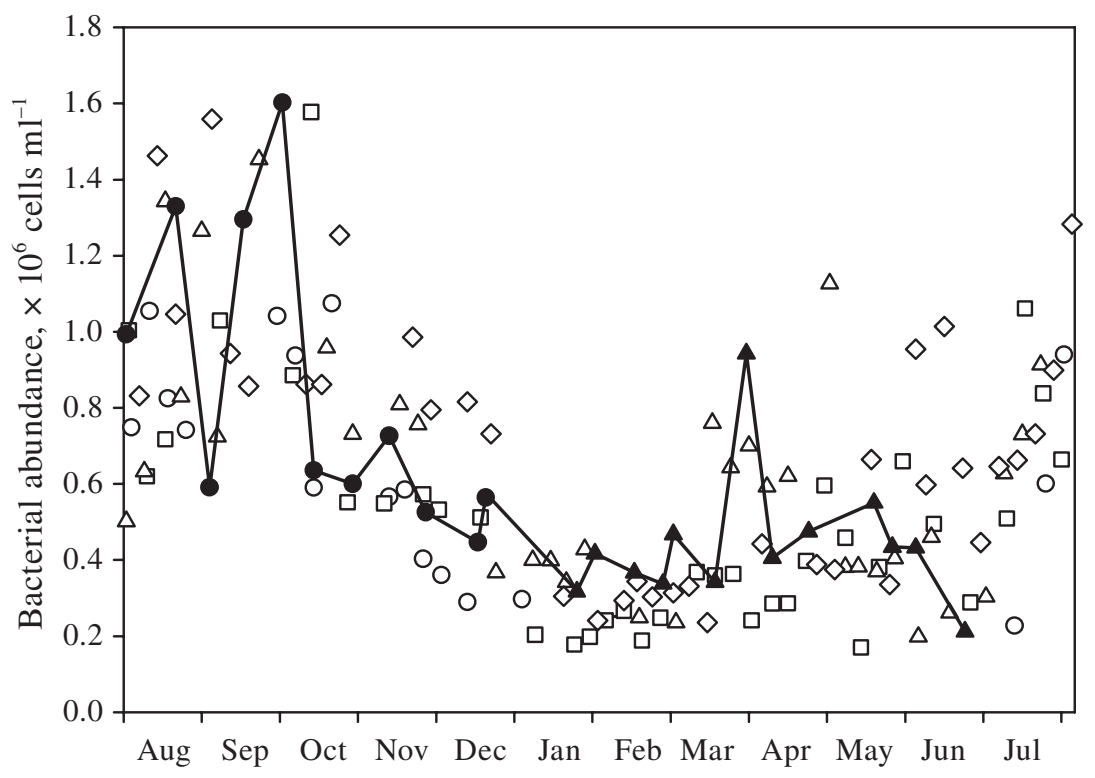

Fig. 1. Seasonal changes of total bacterial abundance measured at Stn L4, Plymouth, UK. O: 1998; $\square: 1999 ; \Delta: 2000 ; \diamond: 2001 ;$ ○: 2003; $\mathbf{\Delta}: 2004$

\section{Bacterioplankton community structure (FISH)}

The Eubacteria domain dominated over the Archaea domain (Table 2, Fig. 2a). Between 70 and $85 \%$ of all DAPI-stained cells (mean: $80 \%$ ) were visualized with the compilation of Eubacteria probes EUBI-III (Table 1), while Archaea accounted for less than $6 \%$ to a maximum of $13 \%$ of all DAPI-stained cells (mean: $8 \%$ ). Compositional analysis using FISH-TSA revealed that the bacterioplankton at L4 was dominated by the SFB cluster and the $\alpha$-Proteobacteria. On an annual average, members of the SFB group formed $32 \%$ (range: 20 to $51 \%$ ) of of all DAPI-stained cells and $41 \%$ (range: 24 to $61 \%$ of the cells detected by the Eubacteria probes, reaching their maximal abundances in spring and early summer (Table 2, Fig. 2a). $\alpha$-Proteobacteria were the second most abundant bacterial phylogenetic group constituting highest proportions of all bacterioplankton detected in late summer, autumn and winter (August to March). $\alpha$-Proteobacteria accounted for 18 to $36 \%$ (mean $28 \%$ ) of all DAPIstained cells (Table 2 ) and, on average, $35 \%$ of the EUBI-III counts (range: 23 to $50 \%$ ). $\alpha$-Proteobacteria were dominated by SAR 11 clade and Roseobacter genus, representing 8 to $20 \%$ and 1 to $11 \%$ of all bacterioplankton respectively. SAR11 clade seemed to follow the same pattern as the $\alpha$ subclass, whereas the Roseobacter genus significantly increased in early spring and summer with a maximum in May (Table2, Fig. 2b). The sum of cells targeted by the probes RSB67 specific for Roseobacter clade and SAR11 was generally smaller than the number of cells targeted by the general $\alpha$-Proteobacteria probe Alf968. Indeed, the $16 \mathrm{~S}$ 
Table 2. Seasonal changes of bacterioplankton community structure at Stn L4 between August 2003 and July 2004, normalised as percentages of TSA-FISH positive cells compared to total DAPI positive cells. Counts of $\sim 1000$ cells from 8 to 10 randomly chosen fields on the filters (mean $\pm \mathrm{SD}$ ). Comparison between 2 consecutive months using $t$-tests, ${ }^{*}: 95 \%$ significant difference, ${ }^{* *}: 99 \%$ significant difference, no symbol: difference is insignificant

\begin{tabular}{|c|c|c|c|c|c|c|c|c|}
\hline & Eubacteria & Archea & SFB & $\alpha$-Proteobacteria & SAR11 & Roseobacter & $\gamma$-Proteobacteria & SAR86 \\
\hline Jan & $72.1 \pm 10.1^{* *}$ & $8.8 \pm 4.0$ & $19.6 \pm 5.1^{* *}$ & $29.3 \pm 10.0$ & $15.4 \pm 5.9$ & $1.5 \pm 0.4$ & $8.8 \pm 3.9$ & $0.6 \pm 0.3^{* *}$ \\
\hline Feb & $84.4 \pm 5.5$ & $7.9 \pm 2.3$ & $27.8 \pm 6.6$ & $35.8 \pm 7.3^{*}$ & $18.1 \pm 6.3^{* *}$ & $2.0 \pm 0.8^{* *}$ & $8.4 \pm 2.0$ & $0.1 \pm 0.1^{*}$ \\
\hline Mar & $79.0 \pm 13.2$ & $6.6 \pm 3.3$ & $28.0 \pm 8.7^{*}$ & $28.3 \pm 9.9$ & $19.7 \pm 4.9^{*}$ & $4.6 \pm 1.2^{* *}$ & $11.0 \pm 4.1$ & $0.3 \pm 0.1^{* *}$ \\
\hline Apr & $81.3 \pm 7.9^{*}$ & $6.0 \pm 3.9$ & $38.1 \pm 10.9$ & $23.1 \pm 11.9$ & $12.8 \pm 3.2$ & $11.3 \pm 4.0$ & $10.1 \pm 2.9^{*}$ & $1.8 \pm 0.3$ \\
\hline May & $90.0 \pm 8.3$ & $7.8 \pm 2.2$ & $45.5 \pm 7.8$ & $22.4 \pm 6.2$ & $8.9 \pm 3.4$ & $9.3 \pm 2.6$ & $7.0 \pm 2.1$ & $1.5 \pm 0.5$ \\
\hline Jun & $80.0 \pm 12.2$ & $10.2 \pm 4.9$ & $42.5 \pm 9.8$ & $17.6 \pm 5.0$ & $9.1 \pm 4.5$ & $9.1 \pm 3.2$ & $8.2 \pm 1.9^{* *}$ & $2.0 \pm 0.9^{* *}$ \\
\hline Jul & $70.2 \pm 15.7^{*}$ & $7.6 \pm 3.5$ & $51.3 \pm 12.3^{* *}$ & $20.0 \pm 4.7^{*}$ & $11.1 \pm 4.5$ & $8.3 \pm 3.6^{* *}$ & $13.3 \pm 4.2$ & $6.6 \pm 1.3$ \\
\hline Aug & $81.2 \pm 8.2$ & $9.4 \pm 3.5^{*}$ & $33.5 \pm 11.6^{*}$ & $27.6 \pm 8.0$ & $12.5 \pm 3.6$ & $3.6 \pm 0.9$ & $12.5 \pm 4.4$ & $5.1 \pm 1.5^{* *}$ \\
\hline Sep & $76.9 \pm 6.7^{*}$ & $7.0 \pm 2.8^{* *}$ & $21.8 \pm 6.8$ & $35.1 \pm 12.2$ & $12.2 \pm 3.0$ & $3.5 \pm 0.9^{* *}$ & $14.5 \pm 3.8$ & $2.4 \pm 1.2^{* *}$ \\
\hline Oct & $67.3 \pm 6.9^{* *}$ & $12.5 \pm 6.3^{*}$ & $20.1 \pm 6.9$ & $34.7 \pm 10.4$ & $12.4 \pm 2.6$ & $1.2 \pm 0.4$ & $13.1 \pm 5.0$ & $0.8 \pm 0.3$ \\
\hline Nov & $76.2 \pm 4.9$ & $8.8 \pm 3.4$ & $22.9 \pm 8.0$ & $34.4 \pm 6.9$ & $11.4 \pm 3.1$ & $1.0 \pm 0.3$ & $10.1 \pm 2.9$ & $1.2 \pm 0.8$ \\
\hline Dec & $70.0 \pm 12.3$ & $7.9 \pm 2.1$ & $22.3 \pm 6.2$ & $27.6 \pm 10.3$ & $13.9 \pm 4.1$ & $1.0 \pm 0.1^{* *}$ & $9.2 \pm 3.3$ & $1.0 \pm 0.5$ \\
\hline
\end{tabular}

database used to generate the probes was not exhaustive and many taxa from the bacterioplankton appeared to correspond to novel lineages not yet represented in the general databases. $\gamma$-Proteobacteria always comprised the lowest proportions of all bacterial groups (Table 2, Fig. 2c), accounting for 8 to $16 \%$ of all DAPIstained cells (mean $11 \%$ ) and, on average, $14 \%$ of the EUBI-III counts (range: 10 to $19 \%$ ). The SAR86 cluster of $\gamma$-Proteobacteria was $\sim 8 \%$ of all bacterioplankton in summer and could represent less than $1 \%$ in winter (Table2, Fig. 2c). Moreover, it represented $\sim 50 \%$ of the $\gamma$-Proteobacteria in summer and seems to follow the same seasonal variation as $\gamma$-Proteobacteria.

An $F$-test was carried out to examine the variance between the bacterial groups and total bacterioplankton abundance (Table 3). The result suggests that there is significantly greater variability in the monthly abundances of Roseobacter and SAR86 cluster compared to the total abundance. This supports the hypothesis that the more specific the taxonomic discrimination is, the greater variability in seasonal abundance is observed. However, the high variance in the Roseobacter and SAR86 cluster is driven by one or two relatively high peaks whilst throughout much of the year, particularly the winter, their abundance is consistently relatively low.

\section{DISCUSSION}

\section{Methodological aspect}

Within the last decade, new methods have been described for the study of microbial population dynamics in the marine picoplankton. Denaturing gradient gel electrophoresis (DGGE) has been an attractive approach to study bacterioplankton diversity because it allows a rapid qualitative analysis of the phylogenetic structure of bacterial communities. Its application revealed rather stable seasonal as well as pronounced temporal and spatial variations of bacterial communities in aquatic systems (e.g. Lebaron et al. 1999, Lindström 2000, Riemann \& Winding 2001). However, because of biases introduced by $\mathrm{PCR}$, including disproportionately frequent recovery of some sequences and the virtual loss of others (Suzuki \& Giovannoni 1996, Cottrell \& Kirchman 2000a), quantitative assessment of the contributions of particular groups of bacteria has been problematic (Schauer et al. 2003). Fluorescence in situ hybridization (FISH) (e.g. Wagner et al. 1994, Manz 1999) is the other method of choice for looking at bacterial composition and has the advantage of allowing a quantitative determination of the relative abundances of different phylogenetic groups of bacteria (e.g. Glockner et al. 1999, Pernthaler 2002a, 2004). It was also used to determine the factors controlling the bacterial community in freshwater systems (Liu \& Leff 2002). In the present study between 85 and $100 \%$ of the Bacteria were identified by FISH as members of the SFB cluster and $\alpha$ - and $\gamma$-Proteobacteria, indicating that a substantial fraction of the bacterioplankton community could be phylogenetically characterised. However, compared to the DGGE method that allows identification of unknown populations by sequencing bands, the $16 \mathrm{~S}$ database used to generate the FISH probes is not exhaustive and bacterioplankton of novel lineages not yet represented in the general databases remained unidentifiable.

\section{Bacterioplankton community structure}

Between 85 and $100 \%$ of the Bacteria were identified as members of the SFB group and $\alpha$ - and $\gamma$-Proteobacteria which appears to be characteristic for marine 

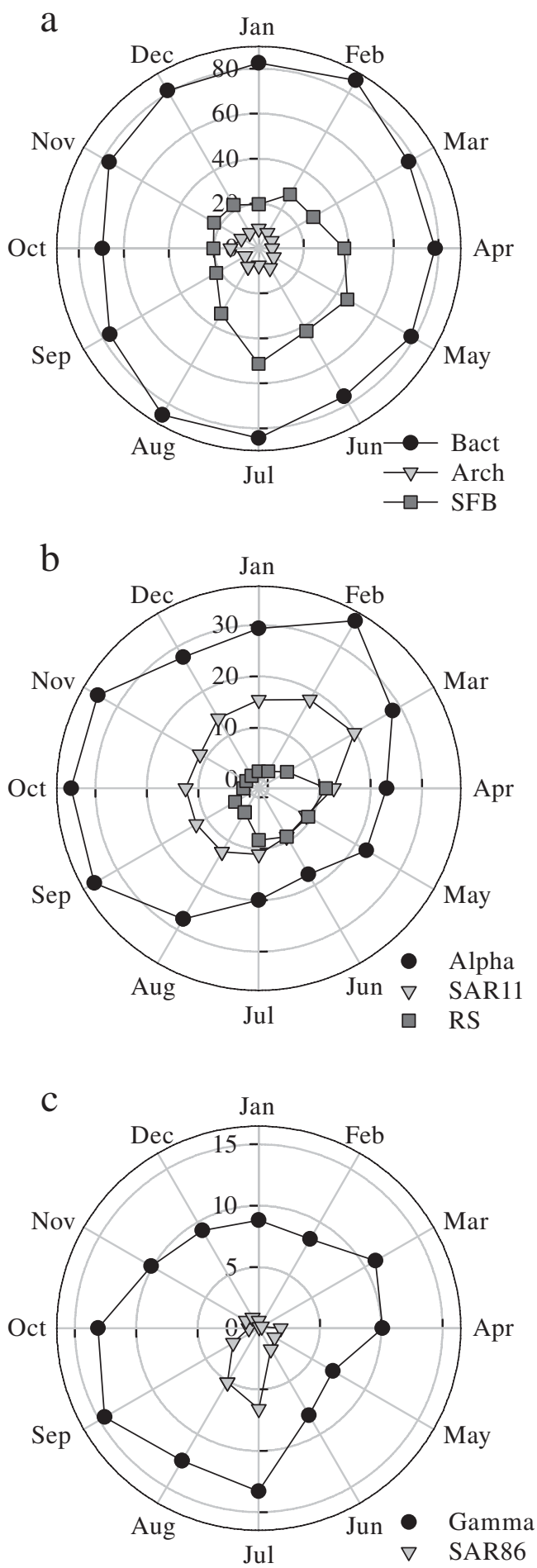

Fig. 2. Seasonal changes in bacterioplankton community structure (relative abundance, \%) at L4 between August 2003 and August 2004 studied using TSA-FISH (Tyramide signal amplification-fluorerscent in situ hybridisation). (a) General class and group specific probes (Cren554, Eury806, CF319a, Table 1) compared to Bacteria (EUBI + EUBII + EUBIII, Table 1); (b) $\alpha$-Proteobacteria at class, clade and genus level (Alf968, RSB67, SAR11-152R + SAR11-542R, Table 1); (c) $\gamma$-Proteobacteria at class and clade level (Gam42a, SAR86/1245, Table 1)
Table 3. Analysis of the variance between the bacterial groups and total bacterioplankton abundance using the F-test. Data have been normalized, so that mean $=0$

\begin{tabular}{|lcc|}
\hline & Variance & $\mathrm{p}$ \\
\hline Total bacterioplankton & 0.34 & \\
Eubacteria & 0.35 & 0.47 \\
Archea & 0.36 & 0.45 \\
SFB & 0.68 & 0.13 \\
$\alpha$-Proteobacteria & 0.29 & 0.41 \\
SAR11clade & 0.31 & 0.44 \\
Roseobacter & 1.29 & 0.02 \\
-Proteobacteria & 0.34 & 0.49 \\
SAR86 cluster & 1.70 & 0.01 \\
\hline
\end{tabular}

bacterioplankton in general (Glockner et al. 1999, Fuchs et al. 2000). These results are consistent with previous studies that showed that $\alpha$-Proteobacteria and SFB were abundant throughout the year in coastal Mediterranean environments (Schauer et al. 2003), off the Oregon Coast (Suzuki et al. 1997), in Great South Bay, in the North Atlantic (Kelly \& Chistoserdov 2001) and from several stations off the California Coast (Cottrell \& Kirchman 2000b).

On an annual average, members of the SFB group reached their maximal abundances in spring and early summer (Table 2, Fig. 2a) when labile organic substrates such as amino acids, proteins and carbohydrates are produced in the course of phytoplankton blooms (Simon et al. 1998, Bunte \& Simon 1999, Rosenstock \& Simon 2001). SFB bacteria were identified as important members of bacterioplankton communities in many aquatic environments including lakes, rivers and marine systems (Pernthaler et al. 1998, Šimek et al. 1999). Their ecological success could be explained by their ability to degrade aerobically at relatively low temperatures (Reichenbach 1992) a large spectrum of organic compounds ranging from various proteins, carbohydrates, to complex macromolecules (Bernardet et al. 1996) abundant in coastal waters.

$\alpha$-Proteobacteria were the second most abundant bacterial phylogenetic group constituting highest proportions of all bacterioplankton detected in late summer, autumn and winter (August to March). There is very limited information available on the occurrence of this subclass of Proteobacteria, making it difficult to explain their abundance. There is some evidence that limnic $\alpha$-Proteobacteria comprise bacteria which prefer rather labile organic matter, although more studies need to be carried out to shed more light on the specific properties of members of this subclass of Proteobacteria (Zwisler et al. 2003). In marine systems, the relative abundance of $\alpha$-Proteobacteria ranges between $1 \%$ in the North Sea and $14 \%$ in the Baltic Sea (Glockner et al. 1999). 
To better understand the dynamic of this diverse group, more specific phylogenetic affiliations were carried out using probes specific for ecologically important lineages. $\alpha$-Proteobacteria were dominated by 2 lineages: the SAR11 clade which made up to $69 \%$ of $\alpha$-Proteobacteria and the Roseobacter genus which accounted for up to $11 \%$ (Table 2, Fig. 2b, c). The SAR11 clade was among the first groups of marine bacteria to be identified by cultivation-independent approaches and appears to dominate subtropical surface bacterioplankton communities (Morris et al. 2002, Rappé et al. 2002). Although the biogeochemical role of the SAR11 clade remains uncertain, this group has been considered to be among the most successful organisms on Earth (Morris et al. 2002). Recently, Malmstrom et al. (2004) showed that SAR11 bacteria could be responsible for about $50 \%$ of amino acid assimilation and $30 \%$ of dimethylsulphoniopropionate (DMSP) assimilation in surface waters of the North Atlantic Ocean, suggesting that they are highly active and play a significant role in $\mathrm{C}, \mathrm{N}$, and $\mathrm{S}$ cycling in the ocean.

The marine Roseobacter genus represents the second most abundant lineage of marine bacterioplankton after SAR11 (Allgaier et al. 2003, Selje et al. 2004). This group was found to be the second most abundant subgroup of $\alpha$-Proteobacteria in coastal waters at L4, especially in summer when its abundance increased considerably. The Roseobacter genus, was also an abundant bacterioplankton component in the Celtic and North Seas (Eilers et al. 2001, Zubkov et al. 2001a, Wagner-Dobler et al. 2003).

While $\gamma$-Proteobacteria represented a lower proportion of the bacterioplankton throughout the year, we were also interested in understanding the dynamic of this group at a lower phylogenetic level. Giovannoni \& Rappé (2000) hypothesized that the SAR86 clade members, ecologically successful heterotrophs in the surface ocean, are most likely utilizing phytoplanktonderived dissolved organic matter, and that their dominance may be the result of a competitive advantage in procuring limited inorganic nutrients. In the present study, SAR86 cluster was found to account for up to half of $\gamma$-Proteobacteria in summer. It was shown previously that this clade might be an important contributor to total bacterioplankton activity in coastal North Sea water during periods of low phytoplankton primary production (Pernthaler et al. 2002a) and played a significant role in the DMSP sulphur uptake (Vila et al. 2004).

\section{Seasonal dynamics of the bacterioplankton community}

A few studies have addressed temporal changes during a whole seasonal cycle in freshwater (Lindström
1998, Pernthaler et al. 1998) and marine (Murray et al. 1998, Pinhassi \& Hagström 2000, Schauer et al. 2003) environments. Here, we found that community structure at higher taxonomic level did not change dramatically with season but lower level phylogenetic groups showed pronounced seasonal peaks (Table 2, Fig. 2). In a previous study, Schauer et al. (2003) also showed the overall stability in time of the taxonomic composition of the bacterioplankton in a Mediterranean coastal system, with gradual changes throughout the year revealing a substitution of closely related phylotypes during the seasonal cycle. The main factors affecting bacterial composition were the change in DOM supply mediated by different algal populations and the different temperature optima of bacterial populations. Similarly, seasonal shifts in bacterioplankton community composition in freshwater systems were related to shifts in the source and lability of DOM (Pernthaler et al. 1998, Crump et al. 2003). Mesocosm experiments have suggested that nutrients and grazing play a key role in shaping the composition as well as the activity of bacterial communities by regulating abundances (Lebaron et al. 2001, Schafer et al. 2001). Especially, very small and large bacteria seemed to be protected from nanoprotozoan grazing whereas active cells within the medium size-class are preferentially consumed (Epstein \& Shiaris 1992).

\section{CONCLUSIONS}

In the present study, we have shown that bacterioplankton change their abundance seasonally at this coastal site, however, the bacterioplankton community structure at high phylogenetic level changed little (Fig. 2a). At a lower phylogenetic level however, a few bacterial groups showed distinct seasonal abundance patterns, with several groups increasing in relative abundance during particular seasons. What causes the stability in the bacterioplankton communities at a high phylogenetic level, while allowing changes at lower levels, remains to be explained.

Acknowledgements. This work was supported partially by the EU project BASICS grant (EVK3-CT-00078), the NERC M\&FMB grant (NER/T/S/2000/01424) and partially by NERC core programme at NOC. The research of M.V.Z. was supported by the NERC advanced research fellowship (NER/I/S/2000/00898).

\section{LITERATURE CITED}

Alfreider A, Pernthaler J, Amann R, Sattler B, Glöckner FO, Wille A, Psenner R (1996) Community analysis of the bacterial assemblages in the winter cover and pelagic layers of a high mountain lake using in situ hybridization. 
Appl Environ Microbiol 62:2138-2144

Allgaier M, Uphoff H, Felske A, Wagner-Dobler I (2003) Aerobic anoxygenic photosynthesis in Roseobacter clade bacteria from diverse marine habitats. Appl Environ Microbiol 69:5051-5059

Amann R, Krumholz L, Stahl DA (1990) Fluorescent-oligonucleotide probing of whole cells for determinative, phylogenetic, and environmental studies in microbiology. J Bacteriol 172:762-770

Amann R, Ludwig W, Schleifer KH (1995) Phylogenetic identification and in situ detection of individual microbial cells without cultivation. Microbiol Rev 59:143-169

Amann R, Glöckner FO, Neef A (1997) Modern methods in subsurface microbiology: in situ identification of microorganisms with nucleic acid probes. FEMS Microbiol Rev 20:191-200

Arrieta JM, Herndl GJ (2002) Changes in bacterial $\beta$-glucosidase diversity during a coastal phytoplankton bloom. Limnol Oceanogr 47:594-599

Azam F (1998) Microbial control of oceanic carbon flux: the plot thickens. Science 280:694-696

Bernardet JF, Segers P, Vancanneyt M, Berthe F, Kersters K, Vandamme P (1996) Cutting a gordian knot: emended classification and description of the genus Flavobacterium, emended description of the family Flavobacteriaceae, and proposal of Flavobacterium hydatis nom. nov. (basonym, Cytophaga quatilis Stohl and Tait 1978). Int J Syst Bacteriol 46:128-148

Biegala IC, Kennaway G, Alverca E, Lennon JF, Vaulot D, Simon N (2002) Identification of bacteria associated with dinoflagellates (Alexandrium spp.) using TSA-FISH (Tyramide signal amplification-fluorescent in situ hybridization) and confocal microscopy. J Phycol 38:404-411

Bunte C, Simon M (1999) Bacterioplankton turnover of dissolved free monosaccharides in a mesotrophic lake. Limnol Oceanogr 65:3843-3849

Cottrell MT, Kirchman DL (2000a) Community composition of marine bacterioplankton determined by $16 \mathrm{~S}$ rRNA gene clone libraries and fluorescence in situ hybridization. Appl Environ Microbiol 66:5116-5122

Cottrell MT, Kirchman DL (2000b) Natural assemblages of marine proteobacteria and members of the CytophagaFlavobacter cluster consuming low- and high-molecularweight dissolved organic matter. Appl Environ Microbiol 66:1692-1697

Crump BC, Kling GW, Bahr M, Hobbie JE (2003) Bacterioplankton community shifts in an arctic lake correlate with seasonal changes in organic matter source. Appl Environ Microbiol 69:2253-2268

Daims H, Brühl A, Amann R, Schleifer KH, Wagner M (1999) The domain-specific probe EUB338 is insufficient for the detection of all bacteria: development and evaluation of a more comprehensive probe set. Syst Appl Microbiol 22:434-444

Ducklow HW (2000) Bacterioplankton production and biomass in the oceans. In: Kirchman D (ed) Microbial ecology of the oceans, Vol 4. Wiley, New York, p 85-120

Ducklow HW, Carlson CA (1992) Oceanic bacterial production. In: Marshall KC (ed) Advances in microbial ecology, Vol 12. Plenum Press, New York, p 113-181

Eilers H, Pernthaler J, Peplies J, Glockner FO, Gerdts G, Amann R (2001) Isolation of novel pelagic bacteria from the German bight and their seasonal contributions to surface picoplankton. Appl Environ Microbiol 67:5134-5142

Epstein SS, Shiaris MP (1992) Size-selective grazing of coastal bacterioplankton by natural assemblages of pigmented flagellates, colorless flagellates and ciliates. Microbiol Rev 23:211-225
Fandino LB, Riemann L, Steward GF, Long RA, Azam F (2001) Variations in bacterial community structure during a dinoflagellate bloom analyzed by DGGE and 16S rDNA sequencing. Aquat Microb Ecol 23:119-130

Fuchs BM, Zubkov MV, Sahm K, Burkill PH, Amann R (2000) Changes in community composition during dilution cultures of marine bacterioplankton as assessed by flow cytometric and molecular biological techniques. Environ Microbiol 2:191-201

Giovannoni SJ, Rappé MS (2000) Evolution, diversity and molecular ecology of marine prokaryotes. In: Kirchman DL (ed) Microbial ecology of the oceans. Wiley \& Sons, p 47-84

Glockner FO, Fuchs BM, Amann R (1999) Bacterioplankton compositions of lakes and oceans: a first comparison based on fluorescence in situ hybridization. Appl Environ Microbiol 65:3721-3726

Hahn MW, Hofle MG (2001) Grazing of protozoa and its effect on populations of aquatic bacteria. FEMS Microbiol Ecol 35:113-121

Hiorns WD, Methe BA, Nierzwicki-Bauer SA, Zehr JP (1997) Bacterial diversity in Adirondack mountain lakes as revealed by $16 \mathrm{~S}$ rRNA gene sequences. Appl Environ Microbiol 63:2957-2960

Hofle MG, Haas H, Dominik K (1999) Seasonal dynamics of bacterioplankton community structure in a eutrophic lake as determined by 5S rRNA analysis. Appl Environ Microbiol 65:3164-3174

Kelly KM, Chistoserdov AY (2001) Phylogenetic analysis of the succession of bacterial communities in the Great South Bay (Long Island). FEMS Microbiol Ecol 35:85-95

Lebaron P, Servais P, Trousselier M, Courties C and 7 others (1999) Changes in bacterial community structure in seawater mesocosms differing in their nutrient status. Aquat Microb Ecol 19:255-267

Lebaron P, Servais P, Troussellier M, Courties C and 7 others (2001) Microbial community dynamics in Mediterranean nutrient-enriched seawater mesocosms: changes in abundances, activity and composition. FEMS Microbiol Ecol 34:255-266

Lindström ES (1998) Bacterioplankton community composition in a boreal forest lake. FEMS Microbiol Ecol 27:163-174

Lindström ES (2000) Bacterioplankton community composition in five lakes differing in trophic status and humic content. Microbial Ecol 40:104-113

Liu J, Leff LG (2002) Temporal changes in the bacterioplankton of a Northeast Ohio (USA) River. Hydrobiologia 489: $151-159$

Malmstrom RR, Kiene RP, Cottrell MT, Kirchman DL (2004) Contribution of SAR11 bacteria to dissolved dimethylsulfoniopropionate and amino acid uptake in the North Atlantic ocean. Appl Environ Microbiol 70:4129-4135

Manz W (1999) In situ analysis of microbial biofilms by rRNAtargeted oligonucleotide probing. Methods Enzymol 310: 79-91

Manz W, Amann R, Ludwig W, Wagner M, Schleifer KH (1992) Phylogenetic oligonucleotide probes for the major subclasses of proteobacteria: problems and solutions. Syst Appl Microbiol 15:593-600

Manz W, Amann R, Ludwig W, Vancanneyt M, Schleifer KH (1996) Application of a suite of 16S rRNA-specific oligonucleotide probes designed to investigate bacteria of phylum Cytophaga-Flavobacter-Bacteroides in the natural environment. Microbiology 142:1097-1106

Marie D, Partensky F, Jacquet S, Vaulot D (1997) Enumeration and cell cycle analysis of natural populations of marine picoplankton by flow cytometry using the nucleic acid 
stain SYBR Green I. Appl Environ Microbiol 63:186-193

Massana R, Murray AE, Preston CM, DeLong EF (1997) Vertical distribution and phylogenetic characterization of marine planktonic Archaea in the Santa Barbara Channel. Appl Environ Microbiol 63:50-56

Morris RM, Rappé MS, Connon SA, Vergin KL, Siebold WA, Carlson CA, Giovannoni SJ (2002) SAR11 clade dominates ocean surface bacterioplankton communities. Nature 420:806-810

Murray AE, Preston CM, Massana R, Taylor LT, Blakis A, Wu K, DeLong EF (1998) Seasonal and spatial variability of bacterial and archaeal assemblages in the coastal waters near Anvers Island, Antarctica. Appl Environ Microbiol 64:2585-2595

Pernthaler J, Alfreider A, Posch T, Andreatta S, Psenner R (1997) In situ classification and image cytometry of pelagic bacteria from a high mountain lake (Gossenköllesee, Austria). Appl Environ Microbiol 63:4778-4783

Pernthaler J, Glockner FO, Unterholzner S, Alfreider A, Psenner R, Amann R (1998) Seasonal community and population dynamics of pelagic bacteria and archaea in a high mountain lake. Appl Environ Microbiol 64:4299-4306

Pernthaler A, Pernthaler J, Amann R (2002a) Fluorescence in situ hybridization and catalyzed reporter deposition for the identification of marine bacteria. Appl Environ Microbiol 68:3094-3101

Pernthaler A, Preston CM, Pernthaler J, DeLong EF, Amann R (2002b) Comparison of fluorescently labeled oligonucleotide and polynucleotide probes for the detection of pelagic marine bacteria and archaea. Appl Environ Microbiol 68:661-667

Pernthaler J, Zollner E, Warnecke F, Jurgens K (2004) Bloom of filamentous bacteria in a mesotrophic lake: identity and potential controlling mechanism. Appl Environ Microbiol 70:6272-6281

Pinhassi J, Hagström $\AA$ (2000) Seasonal succession in marine bacterioplankton. Aquat Microb Ecol 21:245-256

Rappé MS, Connon SA, Vergin KL, Giovannoni SJ (2002) Cultivation of the ubiquitous SAR11 marine bacterioplankton clade. Nature 418:630-633

Reichenbach H (1992) The order Cytophagales. In: Balows A, Truper HG, Dworkin M, Hardin W, Schleifer (eds) The prokaryotes, 2nd edn. Springer-Verlag, New York, p 3631-3675

Riemann L, Winding A (2001) Community dynamics of free-living and particle-associated bacterial assemblages during a freshwater phytoplankton bloom. Microb Ecol 42: 274-285

Rosenstock B, Simon M (2001) Sources and sinks of dissolved amino acids and proteins in a large and deep mesotrophic lake. Limnol Oceanogr 46:644-654

Schäfer H, Bernard L, Courties C, Lebaron P and 7 others (2001) Microbial community dynamics in Mediterranean nutrient-enriched seawater mesocosms: changes in the genetic diversity of bacterial populations. FEMS Microbiol Ecol 34:243-253

Schauer M, Balagué V, Pedrós-Alió C, Massana R (2003) Seasonal changes in the taxonomic composition of bacterioplankton in a coastal oligotrophic system. Aquat Microb Ecol 31:163-174

Selje N, Simon M, Brinkhoff T (2004) A newly discovered Roseobacter cluster in temperate and polar oceans. Nature

Editorial responsibility: Karel Šimek,

Ceské Budějovice, Czech Republic
427:445-448

Šimek K, Kojecká P, Nedoma J, Hartman P, Vrba J, Dolan JR (1999) Shifts in bacterial community composition associated with different microzooplankton size fractions in a eutrophic reservoir. Limnol Oceanogr 44:1634-1644

Simon M, Tilzer MM, Müller H (1998) Bacterioplankton dynamics in a large mesotrophic lake: I. Abundance, growth and relationships to phytoplankton growth. Arch Hydrobiol 143:385-407

Suzuki MT, Giovannoni SJ (1996) Bias caused by template annealing in the amplification of mixtures of $16 \mathrm{~S}$ rRNA genes by PCR. Appl Environ Microbiol 62:625-630

Suzuki MT, Rappé M, Haimberger ZW, Winfield H, Adair N, Ströbel J, Giovannoni SJ (1997) Bacterial diversity among small-subunit rRNA gene clones and cellular isolates from the same seawater sample. Appl Environ Microbiol 63: 983-989

van Hannen EJ, Zwart G, van Agterveld MP, Gons HJ, Ebert J, Laanbroeck HJ (1999) Changes in bacterial and eukaryotic community structure after mass lysis of filamentous cyanobacteria associated with viruses. Appl Environ Microbiol 65:795-801

Vila M, Simo R, Kiene RP, Pinhassi J, Gonzalez JM, Moran MA, Pedros-Alio C (2004) Use of microautoradiography combined with fluorescence in situ hybridization to determine dimethylsulfoniopropionate incorporation by marine bacterioplankton taxa. Appl Environ Microbiol 70: 4648-4657

Wagner M, Assmus B, Hartmann A, Hutzler P, Amann R (1994) In situ analysis of microbial consortia in activated sludge using fluorescently labelled, rRNA-targeted oligonucleotide probes and confocal scanning laser microscopy. J Microsc 176:181-187

Wagner-Dobler I, Rheims H, Felske A, Pukall R, Tindall BJ (2003) Jannaschia helgolandensis gen. nov., sp. nov., a novel abundant member of the marine Roseobacter clade from the North Sea. Int J Syst Evol Microbiol 53:731-738

Yager PL, Connelly TL, Mortazavi B, Wommack KE, Bano N, Bauer JE, Opsahl S, Hollibaugh JT (2001) Dynamic bacterial and viral response to an algal bloom at subzero temperatures. Limnol Oceanogr 46:790-801

Zaccone R, Caruso G, Cali C (2002) Heterotrophic bacteria in the northern Adriatic Sea: seasonal changes and ectoenzyme profile. Mar Environ Res 54:1-19

Zubkov MV, Fuchs BM, Archer SD, Kiene RP, Amann R, Burkill PH (2001a) Linking the composition of bacterioplankton to rapid turnover of dissolved dimethylsulphoniopropionate in an algal bloom in the North Sea. Environ Microbiol 3:304-311

Zubkov MV, Fuchs BM, Burkill PH, Amann R (2001b) Comparison of cellular and biomass specific activities of dominant bacterioplankton groups in stratified waters of the Celtic Sea. Appl Environ Microbiol 67:5210-5218

Zubkov MV, Fuchs BM, Archer SD, Kiene RP, Amann R, Burkill PH (2002) Rapid turnover of dissolved DMS and DMSP by defined bacterioplankton communities in the stratified euphotic zone of the North Sea. Deep-Sea Res II 49:3017-3038

Zwisler W, Selje N, Simon M (2003) Seasonal patterns of the bacterioplankton community composition in a large mesotrophic lake. Aquat Microb Ecol 31:211-225

Submitted: May 4, 2005; Accepted: December 5, 2005

Proofs received from author(s): February 11, 2006 